\title{
遅発性脳血管卛縮の病理学的検討
}

\author{
楜 寿右・谷掛 龍夫・京井喜久男・内海庄三郎 \\ 村田 吉郎*・日浅 義雄*・菊池 晴彦**
}

\section{Pathological Study of Late Arterial Spasm}

\author{
Toshisuke Sakaki, Tatsuo Tanigake, Kikuo Kyoi, Shozaburo Utumi, \\ Yoshio Murata*, Yoshio Hiasa* and Haruhiko Kikuchi** \\ Division of Neurosurgery, Nara Medical University \\ * First Division of Pathology, Nara Medical University \\ **Division of Neurosurgery, National Cardiovascular Center
}

\begin{abstract}
Summary
It is well known that cercbral vasospasm following ruptured cerebral ancurysm affects the prognosis very seriously after direct surgery. However, the pathogenesis of cerebral vasospasm remains obscure. Furthermore, the precise brain damage following it has not been made clear histopathologically.

The histopathological postmortem studics of intracranial arteries with angiographycally demonstrated arterial narrowing have been carried out in 44 cases.

The cerebral arterial wall corresponding to the angiographic vasospasm showed various structural changes, which could be divided into five groups according to histological findings.

In Group 1, the intraluminal size of arterial wall was reduced even though the medial thickening, marked corrugation of the internal elastic lamina and intimal edema were demonstrated. In Group 2, necrosis of smooth muscle cells in the tunica media, partial break of internal elastic lamina and the profuse deposition of acid mucopolysaccharides were seen. In Group 3, marked intimal thickening and the medial atrophy were seen. In Group 4, dilatation of luminal size with improvement of the intimal thickening and the remarkable medial atrophy were noted. In Group 5, regeneration of smooth muscle cell in the tunica media was observed.

These histological findings suggest the time course of cerebral arterial spasm from onset to remission.
\end{abstract}

Key words : subarachnoid hemorrhage, late arterial spasm, aneurysm

\section{I はじめに}

1951年，Ecker and Riemenschneider ${ }^{5>} か ゙ ク モ$ 膜下出 血後に動脈内腔の狭窄現象の発生を初的て血管撮影上に 認めた。破裂脳動脈瘤念性期の病態が明らかにされるに つれ，その狭案現象の発生頻度の高いこともわか门，脳 血管摹縮と把握されるに至っている，このいわゆる脳血

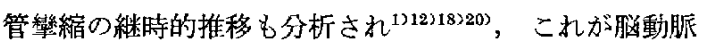

瘤破裂後の患者の予後を左右する重要な因子と考えられ ている2211. したがって，再出血防止の手段としての頭 蓋内直達手術が脳動脈瘤の治療法として確立されしつつあ る現在この脳血管彎縮に刘する対策こそ，大きな課題 といわねばならない，しかし，いまなおこの脳血管繁縮 の本態さえ解明されていない．

従来，この脳血管綪縮は血管撮影像上の血管の狭窄々 拡張，つまり脳動脈の機能的な収縮と弛緩であると考え

奈良県立医科大学脳神経外科

*奈良県立医科大学第一病理

**国立循環器病センター脳神释外科

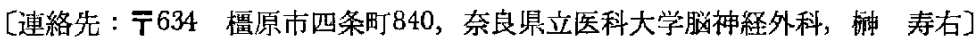

1979年 5 月 7 日 受稿 
られ，動脈瘤加らの再出血防止のための防衛的機能的生 理現象と思われていた ${ }^{8220)}$.だが単なる機能的な收縮に しては，収縮の時間が長すぎること，㘘縮の宽解を示し た動脈法、取縮以前の状態上り拉張が括こりらるこ と，臂縮後に時々遠位部動脈の閉塞がタられることなど 加ら熬縮血管に病理組織学的変化が発生もしくは随伴し ている可能性が十分に考えられる。そこで著者らは，こ の機能的変化と思われていた脳血管揫縮と病理組織学的 変化との関連性追筑寸るため，出血発作で発症し，腷 血管撮影に上り血管孌縮が確認され，その後種々の時期 に死亡した症例について, 脳血管病理学的に検討し た. その結果, 病理学的にも血管撮影所見の推移を裹う ける成績をえた。

\section{II 研究 対象}

昭和47年 4 月から昭和53年10月までに，奈良県立医科 大学脳神释外科㧍上びその関速病院に扔いて, 脳動脈癌 破裂によるクモ膜下计血の発作後死亡し，かつ剖検しえ

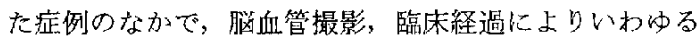

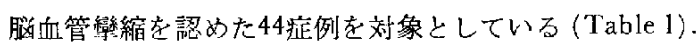
こ礼らの症例は34才加ら68才までの男性20例，女性24例 で好り，クモ膜下出血発作加死亡屯での期閪は10日以 内8例，11日加ら20日まで17例，21 日から50日まで9 例，51日以後半年まで 6 例，半作以後 3 年の症例方 4 例 である。また，動脈㿇の部位は内頸動脈11例，中大这動 脈13例, 前交通動脈18例, 椎骨動脈 2 例であり, これら の5ち動脈瘤への直達手術が行われたものは24例であ

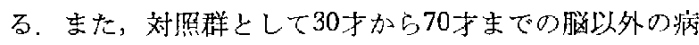
変で死亡した22症例の脳血管も検索した。

\section{II 研究方法}

\section{1. 脳血管撮影像の検討}

脳動脈の病理学的变化をみる時, それが脳血管撮影像 上のどのよらな所見の洔のものなの索知る必要がある ため，まず44症例中内䋶動脈系に動脈瘤を有し，血管撮 影で攣縮方証明された39症例にすける血管撮影像の時閒 的推移について検討した。

脳血管摄影に晾计る繁縮の分類は，通常(1先細り型の tapering, (2) smooth な narrowing diffuse narrowing, (3) $2 \mathrm{~cm}$ 以下の segmental narrowing, (4)局所的飞不規則な内䐋狭窄老示す nodular narrowing, の4型の分類 ${ }^{203}$ が用いられている.しかし，本研究では 便宜上，前 2 者を diffuse narrowing，後 2 者を irrcgular narrowing と 2 群に分類し，発症後の時間的推移との関 係をみた。

\section{2. 脳動脈の組織学的検索方法}

剖梌後, 摘出腷注直ちに $10 \%$ 中性ホルマリンで 2 週な いし 1 力月固定し，その後 Willis 輪を中心に絧主幹動脈 基始部（内钼動脈・椎骨動脈頭蓋内起始部）加占皮質動 脈の末梢に至るむで，可能なかぎり長く血管を採取し た. これを $5 \mathrm{~mm}$ 間隔で切断し，脱水後パラフィン包埋 した。 な㧍，血管分枝部は検索の対象から除外した。

パラフィン包理された各組織はそれぞれ $2 \sim 3 \mu$ の厚 さで薄切し，へマトキシリンエオジン，アザンマロリ 一, ロンギーソンエラスチカ, PAS, アルシアンブルー の各染色法で染色した，そして，これらの標本を血管撮

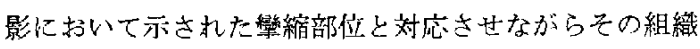
所見について光影的に検討した.

またPAS，アルシアンブルー染色にて陽性であった 標本に対して注，酸性ムコ多糖類の種類の同定を目的上 して, Sasai の力法 ${ }^{23)}$ に上り $0.02 \mathrm{Mol}$ 酢酸緩衝液 ( $\mathrm{pH}$ 5.0）に $0.1 \mathrm{Mol}$ 食塩液と放線菌ヒアルロニダーゼ 30 $\mathrm{TRU} / \mathrm{m} l$ 加え, $37^{\circ} \mathrm{C} 12$ 時間の消化処理を施行した.

\section{IV 結 果}

\section{1. 血管撮影上における輩縮の時間推移}

血管撮影像からまったく攀縮のないものを○, diffuse narrowing を示すものをや，irregular narrowing 老す

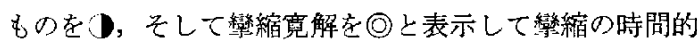

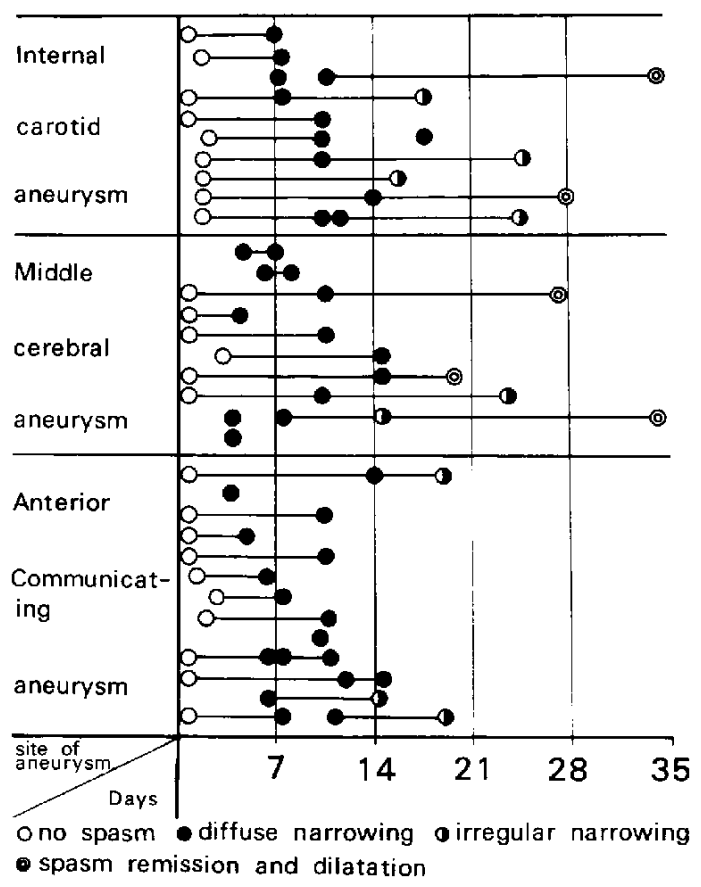

Fig. 1 Time course of angiographic vasospasm. 
Table 1 Summary of 44 cases of SAH with evidence of cerebral artery spasm

\begin{tabular}{|c|c|c|c|c|c|}
\hline $\begin{array}{l}\text { Case } \\
\text { No. }\end{array}$ & $\begin{array}{l}\text { Sex } \\
\text { Age }\end{array}$ & $\begin{array}{l}\text { From SAH } \\
\text { to death }\end{array}$ & $\begin{array}{l}\text { Site of } \\
\text { aneurysm }\end{array}$ & $\begin{array}{l}\text { From SAH } \\
\text { to ischemia }\end{array}$ & Operation \\
\hline 1 & F $\quad 68$ & 3 days & rt-MCA & 3 days & + \\
\hline 2 & M 50 & 4 days & lt-MCA & 4 days & - \\
\hline 3 & M 42 & 6 days & $\mathrm{AC} \circ \mathrm{A}$ & 5 days & + \\
\hline 4 & F $\quad 63$ & 8 days & $\mathrm{ACoA}$ & 4 days & + \\
\hline 5 & M 43 & 8 days & $\mathrm{rt}-\mathrm{MCA}$ & 5 days & + \\
\hline 6 & F $\quad 60$ & 10 days & $\mathrm{ACoA}$ & 6 days & - \\
\hline 7 & $\mathbf{M} 64$ & 10 days & $\mathrm{ACoA}$ & 5 days & + \\
\hline 8 & F 41 & 10 days & $r t-I C A$ & 7 days & $\ldots$ \\
\hline 9 & F 54 & 11 days & $\mathrm{rt}-\mathrm{MCA}$ & 7 days & + \\
\hline 10 & F 62 & 11 days & $\mathrm{ACoA}$ & 5 days & - \\
\hline 11 & F $\quad 64$ & 12 days & $\mathrm{ACoA}$ & 7 days & + \\
\hline 12 & M 43 & 12 days & $\mathrm{ACoA}$ & 5 days & - \\
\hline 13 & M 43 & 12 days & $\mathrm{VA}$ & 8 days & - \\
\hline 14 & M 68 & 13 days & rt-MCA & 8 days & + \\
\hline 15 & M 54 & 13 days & $\mathrm{ACoA}$ & 8 days & - \\
\hline 16 & M 50 & 13 days & $\mathrm{rt}-\mathrm{MCA}$ & 4 days & + \\
\hline 17 & F 56 & 14 days & ACoA & 10 days & - \\
\hline 18 & F 56 & 15 days & $\mathrm{ACoA}$ & 9 days & - \\
\hline 19 & M 53 & 15 days & $\mathrm{ACoA}$ & 6 days & - \\
\hline 20 & M 43 & 15 days & lt-ICA & 7 days & - \\
\hline 21 & F 46 & 16 days & lt-MCA & 8 days & + \\
\hline 22 & F 48 & 17 days & lt-MCA & 7 days & + \\
\hline 23 & M 50 & 17 days & $\mathrm{ACoA}$ & 12 days & - \\
\hline 24 & F 68 & 18 days & $\mathrm{rt}-\mathrm{MCA}$ & 12 days & + \\
\hline 25 & M 58 & 20 days & $\mathrm{ACoA}$ & 7 days & + \\
\hline 26 & F $\quad 53$ & 21 days & rt-MCA & 7 days & + \\
\hline 27 & M 40 & 22 days & lt-ICA & 8 days & - \\
\hline 28 & F $\quad 62$ & 25 days & $\mathrm{ACoA}$ & 7 days & - \\
\hline 29 & M 56 & 26 days & $A C O A$ & 8 days & - \\
\hline 30 & F 51 & 30 days & lt-MCA & 10 days & + \\
\hline 31 & F 62 & 30 days & $\mathrm{rt}-\mathrm{MCA}$ & 10 days & - \\
\hline 32 & F $\quad 57$ & 33 days & lt-ICA & 10 days & + \\
\hline 33 & M 34 & 43 days & $\mathrm{ACoA}$ & 15 days & + \\
\hline 34 & F 68 & 49 days & $\mathrm{rt}-\mathrm{ICA}$ & 14 days & + \\
\hline 35 & F 55 & 53 days & rt-ICA & 13 days & + \\
\hline 36 & M 43 & 57 days & $\mathrm{rt}-\mathrm{VA}$ & 10 days & - \\
\hline 37 & F 57 & 60 days & rt-ICA & 10 days & + \\
\hline 38 & F 48 & 62 days & lt-ICA & 11 days & - \\
\hline 39 & $\mathbf{M} 44$ & 72 days & lt-ICA & 9 days & + \\
\hline 40 & F 59 & 160 days & rt-ICA & 10 days & + \\
\hline 41 & F 62 & 195 days & $1 \mathrm{t}-\mathrm{ICA}$ & 8 days & + \\
\hline 42 & M 67 & 2 years & $\mathrm{ACoA}$ & 10 days & - \\
\hline 43 & M 66 & 3 years & $\mathrm{ACoA}$ & 8 days & - \\
\hline 44 & F 55 & 3 years & $\mathrm{rt}-\mathrm{MCA}$ & 8 days & + \\
\hline
\end{tabular}

SAH: subarachnoidal hemorrhage MCA: middle cerebral artery VA: vertebral artery
ICA: internal carotid artery

ACoA: anterior communicating artery

Operation: direct surgery to aneurysm 


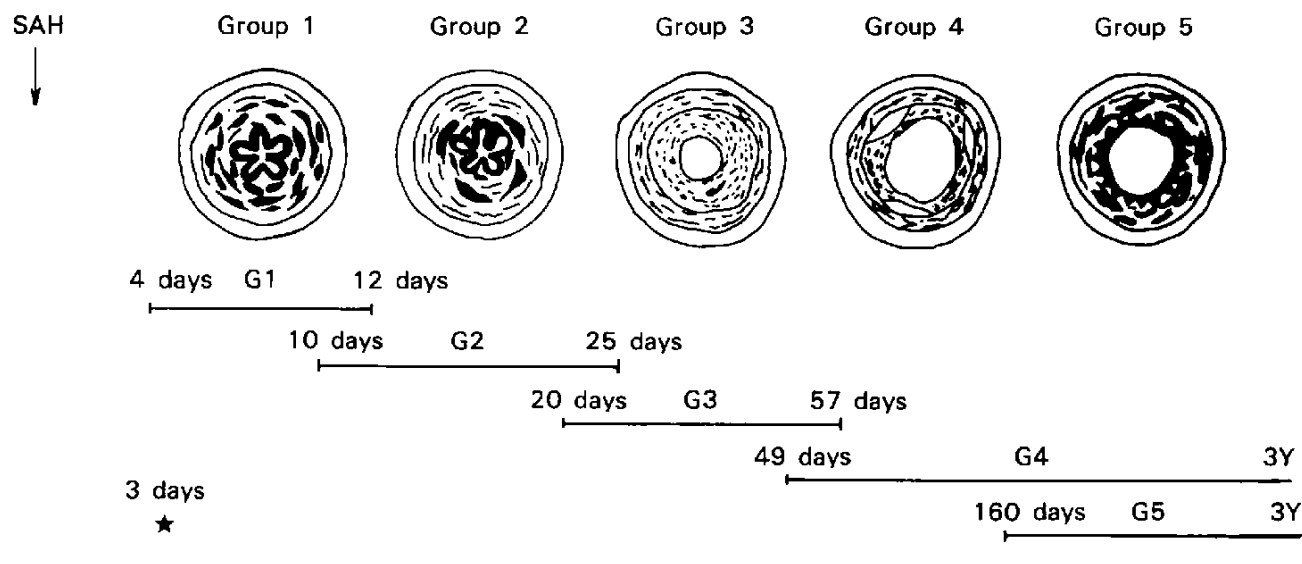

Interval from SAH to Death

Fig. 2

Table 2 Histological findings of large artery with angiospasm

\begin{tabular}{|c|c|c|c|c|}
\hline Histology & $\begin{array}{l}\text { Tunica } \\
\text { Intima }\end{array}$ & $\begin{array}{l}\text { Tunica } \\
\text { Elastica }\end{array}$ & $\begin{array}{l}\text { Tunica } \\
\text { Mcdia }\end{array}$ & $\begin{array}{l}\text { Tunica } \\
\text { Adventitia }\end{array}$ \\
\hline 1 & $\begin{array}{l}\text { slightly } \\
\text { edematous }\end{array}$ & $\begin{array}{l}\text { markedly } \\
\text { irregular }\end{array}$ & $\begin{array}{l}\text { cloudy swelling } \\
\text { of muscle cells } \\
\text { thickening }\end{array}$ & edematous \\
\hline 2 & edematous & $\begin{array}{l}\text { irregular } \\
\text { partial break }\end{array}$ & $\begin{array}{l}\text { Inyonecrosis } \\
\text { macrophages } \\
\text { deposition of } \\
\text { AMPS }\end{array}$ & $\begin{array}{l}\text { cdematous } \\
\text { plasma celts } \\
\text { lymphocytes } \\
\text { hemosiderin-deposits }\end{array}$ \\
\hline 3 & $\begin{array}{l}\text { subendothelial } \\
\text { thickening }\end{array}$ & $\begin{array}{l}\text { atrophy } \\
\text { flattening }\end{array}$ & $\begin{array}{l}\text { atrophy } \\
\text { fibrosis }\end{array}$ & $\begin{array}{l}\text { slight increase of } \\
\text { collagen fibers }\end{array}$ \\
\hline 4 & $\begin{array}{l}\text { remission of } \\
\text { thickening }\end{array}$ & $\begin{array}{l}\text { atrophy } \\
\text { flat tening }\end{array}$ & $\begin{array}{l}\text { atrophy } \\
\text { fibrosis }\end{array}$ & $\begin{array}{l}\text { slight increase of } \\
\text { collagen fibers }\end{array}$ \\
\hline 5 & $\begin{array}{l}\text { slightly } \\
\text { thickening }\end{array}$ & irregular & $\begin{array}{l}\text { muscular } \\
\text { regeneration }\end{array}$ & no change \\
\hline
\end{tabular}

推移をみたのが Fig. 1 である。 クモ膜下出血後 48時閒 以内に等箱像を認めたものは 1 例もない. Diffuse narrowingが出現してくるのは出血発作後 4 日目頃がらであ り，10日前後にピークに達する。そして，14日目㛲加ら 25日目頃に加けて irregular narrowing 定すようにな り，以後掱縮の宽解を示している.

\section{2. 腷動脈の病理学的变化}

1) 主幹動脈の変化

a. 嗦紑部分の血管壁の病理学的変化

44症例の攀縮部分における血管壁の病理学的所見はき わめて多彩である。しかし概観してみると，中膜の肥大を 主景とする群と中膜の萎縮ないしは正常像を主景とする 群に大別される。前者の中膜肥大を示す群で注，内弾性 板の著明な屈帅蛇行, 内腔の狭窄を伴っており，44症例中
26例がこれに該当し，さらに中膜平滑筇細胞に噮死の存 在するるの上そらでないすのがみられる。残りの18例は 後者に該当し，中膜萎維，内膜肥厚のみられるもの上ほ ぼ正常所見に近いものに別けられ，さらにこれの前者で は内膜肥厚の程度が強く内腔狭窄を呈するものと，内腔 肥厚が軽微で内弾性板との閒に fibrinolysis をおこして いるものがある。しかもこれらの諸所見は出血から死亡 までの期間との間に明らかな相関を示している(Fig. 2).

以上加ら44症例の病理学的所見は 5 群に分類できる がその要点を Table 2 に示す. 以下それぞれについて 棓述する。

第 1 群：血管内舼の狭窄があり，内弾性板は著明な届 曲蛇行を示す，中膜は全体の血管经に比して厚く，各中 膜平滑筋細胞は妀縮膨化し，混濁腫脹を示し，細胞質の 


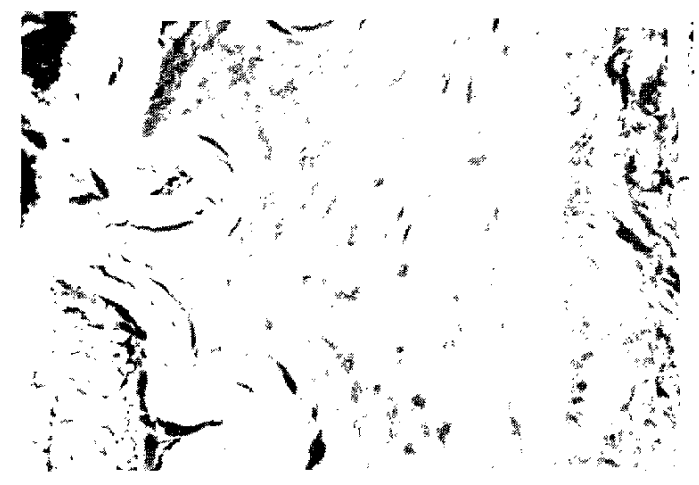

Fig. 3 Histology of middle cerebral artery in Group 1 (Case No. 5). The tunica media is thick and the intcrnal elastic lamina is markcdly corrugated. The cloudy swelling of the medial smooth muscle cells is remarkable. (HE stain. $\times 200$ )

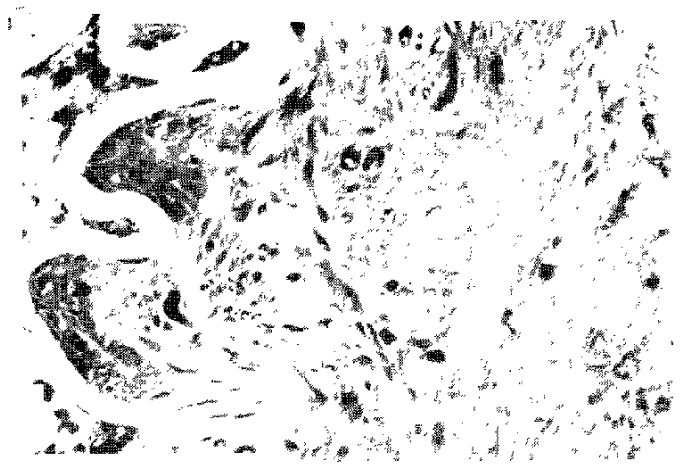

Fig. 4 Histological picture of internal carotid artery in Group 2 (Case No. 14). The tunica media is thick. The internal elastic lamina is markedly corrugated and partially broken down. Necroses of smooth muscle cells and infiltrations of phagocytes are seen. (IHE stain. $\times 200$ )

好堛基性が失和れ好酸性を示寸 (Fig. 3)，外膜には特に 変化を認めない，こ扎らの変化を示方症例 は Case No. $2,3,4,5,8,9,10,12,13 \sigma 9$ 例 で出血発作 4 日 から12日の間に死亡している。

第 2 群：内膜㥒腫状虹し，一部に軽度の肥厚がみ られ，また内皮細胞り脱落も高頻度である。内弹性板は な扣屈曲蛇行が著鹏であるが，第1群の場合より断裂の 頻度が高くなり，症例によって浣完な断裂を示するの

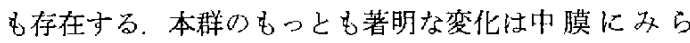
れ，中膜平滑筋辣胞江染色性が低下し，その核は本来の 形熊を失い，暗く濃縮している。また筋線維は円くなっ たり断裂したりしているところるある。外膜の所見注浮 蕾状でリンパ球, プラズマ細胞の軽度存在, へモジデリ

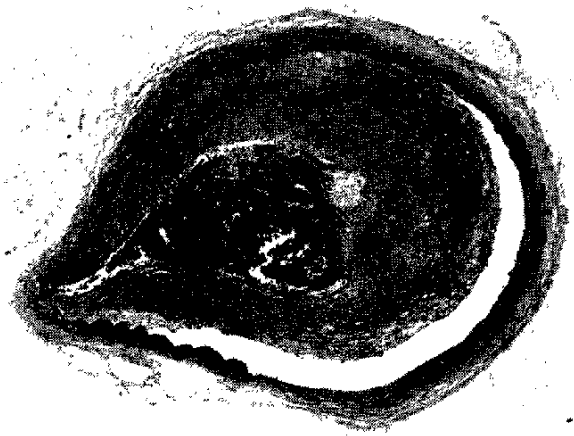

Fig. 5 Histological picture of middle cerebral artery in Group 3 (Case No. 33). The tunica elastica is flat. The tunica media is atrophic. The hypertrophy of tunica intima is remarkable. (Azan-Marolly stain. $\times 40$ )

ンの泌着がみららる (Fig. 4).

さらに中膜筋細胞の罱死が存在する血管には，PAS， フルシアンブルー染色で陽性を示す物 質が中膜の内側 1/3加ら内弹性板周囲に加沙て存在している。この第 2 群の変化は44例中 17 例 (Case No. 6, 7, 11，14，15, $16,17,18,19,20,21,22,23,24,26,27,28)$ に 認兄，これらの症例は出血発作後10日から25日の閒 に死亡している。

第 3 群：もっとも特異的な変化は内膜の肥厚と中膜萎 縮である。内膜汢内皮細胞下に扔いて同心状の線維性增 殖が生じている。この肥厚部分㤌荊原線維，線維細胞， 頜食細胞加成り立って抢り，内腔狭窄加子られる。内 弾性板法萎縮, 扁平化し，断裂老認方ところもある。 また，中膜は萎樎が著明で中膜平滑筋細胞の減少が明ら 加上なって扣り，膠原線維の増加加目立つ，外膜はやや 萎縮を示すがそれ注ど強いるのではない (Fig. 5)。この 第 3 群の知見注 44例中 8 例 (Case No. 25，29，30，31， $32 ， 33 ， 35 ， 36)$ に認められ，これらの症例恃出血発作 後20日から57日の間江死亡している。

第 4 群：内膜の線維性肥厚方少なくなり，特に内膜と 内弾性板の間で浮腫状となって非常に粗な組織搆造を示 す.そのためパラフィン切片では内膜が内弾性板から剝 雄しているような所見を呈する。虫た血管内腔は明らか に摭大して扔り，壁在血栓の形成もまったくみられな W. そして内弾性板，中膜の萎縮も強W (Fig. 6).この 第 4 群の所見俚44症例中 6 例 (Case No. 34，37，38， 39，41，44) に和机，それら甠出血発作後49日目加 3 年の間に死亡している。

第 5 群：内膜の肥厚昌軽度で内腔もほとんど正常の大 きさであり，内弾性板も䚾正常棈造を呈している，中 


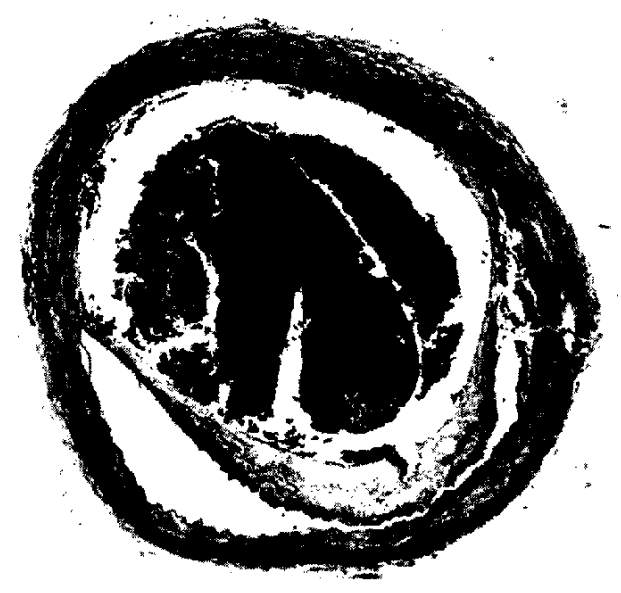

Fig. 6 Histological picture of middle cerebral artery in Group 4 (Case No. 39). The tunica elastica is flat and the atrophy of tunica media is marked. The subendothelial thickening is improved by fibrinolysis. (Azan-Marolly stain. $\times 40$ )

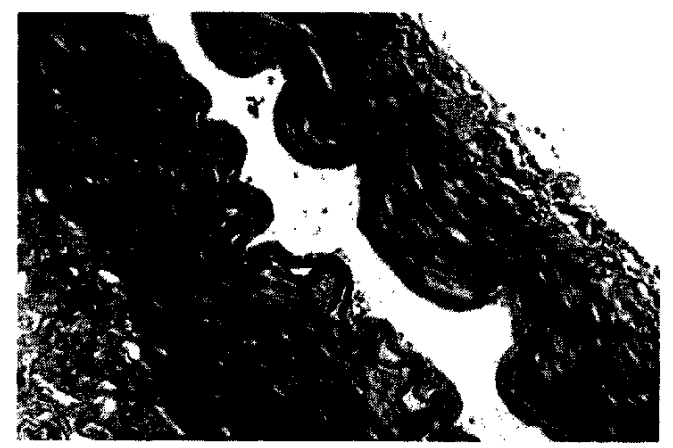

Fig. 7 Histological picture of middle cerebral artery in Group 5 (Case No. 43). The regeneration of smooth muscle cells in tunica media is seen. (HE stain. $\times 100)$

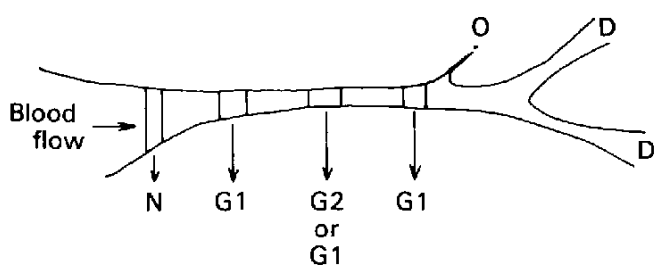

G1 : muscle contraction (cloudy swelling of muscle cell)

G2 : myonecrosis

$\mathrm{O}$ : occlusion (thrombosis)

D : dilatation (loss of vascular tonicity)

Fig. 8 A schema of angiographical diffuse narrowing and localization of pathological changes of diffuse narrowing.

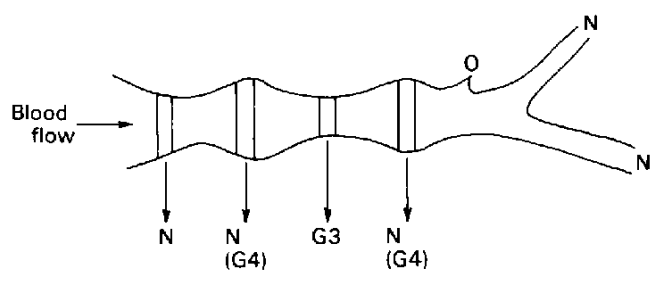

$N$; unremarkable change except slight intimal thickening

G3 : remarkable intimal thickening and medial atrophy

$\mathrm{G} 4$ : slight or moderate intimal thickening and medial atrophy

0 : occlusion (thrombosis)

Fig.9 A schema of angiographical irregular narrowing and localization of pathological changes of irregular narrowing.

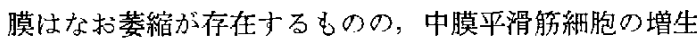
がみられ，膠原線維汪減少している。主た，外膜む任上 んど正常である (Fig. 7).これは出血後160日，2年， 3 年で死亡した症例 (Case No. 40，42，43)に劝られ， さらに出血発作 3 日後に死亡した症例（Case No. 1) \& ほ正常所見に近い動脈搆造を示し，第 5 群に該当する ものである。

\section{b. 数樎近倿部加らの連続的変化}

血管撮影で narrowing を示した動脈には，上記のよう な病理学的変化が認められる。しかし，同一血管のどの 部分でも同一所見がみられるのではなく，さまざまな所 見が混在している。ここで血管撮影像の narrowing 部扝 よびその近傍部分の連続的な変化を検討するため，最終 血管撮影加ら1〜2日の早期に死亡した症例を選び，そ の所見について検討してみる。な揖この該当症例はCase No. $2,3,4,5,6,7,8,9,10,11,12,14,15$, 17, 19, 23, 30の18例である.

Diffuse narrowing の血管 (Fig. 8) : Case No. 2, 3, $4,5,8,9 ， 10,1208$ 例においては, narrowing 傍部ではほぼ正常所見呈し，次第に中膜肥大部が增加 し, narrowing の部分に一致して第 1 群の变化が存在し ている，そして，遠位部では後述する皮質動脈に多ら れるよらな血管の搪張老伴っている、一方同じ diffuse narrowing 走示症例でも, Case No. 6, 7, 11, 14, $15,17,19,23 の 8$ 例では, narrowing の近傍部はほぼ 正常だが， narrowing の部分では第 1 群の変化と第 2 群 の変化が混在している。

Irregular narrowing の秃管 (Fig. 9) :この目的の該 当症例は Case No. 29，30であるが，narrowing 近傍部 では中膜平滑管も比較的よく保たれ，内膜肥厚む軽度で ある.次第に内膜が肥匽し, narrowing の部分に一致し て強い内膜肥厚上中膜萎縮が存在する.

2) 皮質動脈の变化 


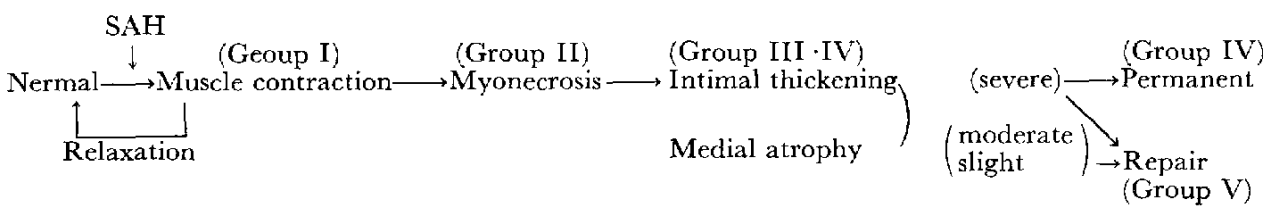

Fig. 10 Time course of pathological findings.

ここに言ら皮質動脈とは，前大脳動脈では半球間槽よ り半球内側面に分布する血管, 中大脳動脈ではシルビウ 不裂から弁蓋部以遠の皮質に分布寸る血管，そして後大 腷動脈では側頭葉・後頭葉皮質に分布寸る血管である， これらの血管は上記主幹動脈とは異なる所見を示してい る.

第 1 - 2 群の皮質動脈：主幹動脈の病理学的変化が第 1・2群であった動脈の遠位部々あたる皮質動脈では， いずれの部分でも内腔が㹡張し，内弾性板は緊張を失。 て弛緩しており，内膜が内弾性板から䗍離し，その間に 浸出液の貯留している部分も存在寸る。文た，主幹動脈 の narrowing が特に著明であった定例では，その末梢部 の皮質動脈の $1 \sim 2$ 本に拡張した腔内に新鮮な血拴の形 成がみられる。

第 3・4 群の皮質動脈：主幹動脈の病理学的变化が第 3・4群であった症例の遠位部皮質動脈㤬汪と九ど正常 所見のもの，血管腔内に器質化した血栓を有するもの， 融解傾向を示す血栓の存在を示寸もの，そして主幹動脈 と同様，内膜の線維性增殖のみられるものが存在する。

第 5 群の皮質動脈：対照群の皮質動脈とほほ同様の所 見でり，病的変化認沈ない。

\section{3. 第 2 群の病理变化を示す標本にみられる PAS,}

\section{アルシアンブルー染色陽性物質の同定}

第 2 群の病理学的所見有子る標本の $64.7 \%$ に招い て,PAS，アルシアンブルー染色で強陽性を示し，他の 所見を有する標本（齐照群では，わずか13.6\%に执いて のみ陽性である）上りきかめて高い陽性率を有してい る。これらの標本に対して放線菌ヒアルロニダーゼを用 いた消化試験を行ったが，その結果，全標本において染 色性の消失を認めている，以上の点上り，この陽性物質 は主としてヒアルロン酸であるといえる。

\section{$\mathrm{V}$ 考察}

攀縮脳血管の病理学的所見は，その組織像の特徴から 5 群に大別することができた，その所見の推移恃，出血 発作から死亡までの期間とかなり密な相関を有してい る。

クモ膜下出血後短時日の間は第 1 群変化一の準備状態
にある、本研究において，第 5 群の所見を有する出血発 作後 3 日目の早期记死亡した Case No. 1 江血管撮影 ですでに中大脳動脈水平部の $2 \mathrm{~cm}$ 以上にわたる diffuse narrowing を示すものであるが，組織学的には注ぼ正常 所見走した。

第 1 群の主要変化は，中膜が血管径に比して厚く，中 膜平滑筋む収綰状熊を示寸ことでこれは出血後種々の原

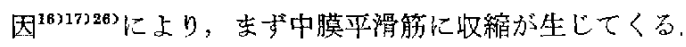
さらに，この状態が長く続くことによって中膜平滑筋に

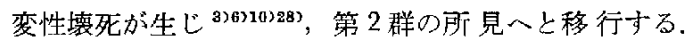
Tanabe $ら^{27)}$ は実験的に中膜平滑筋細胞に填死加生じて くることを証明し，人体材料で注稆ら ${ }^{22)}$ ，Conway ら 金 ${ }^{11)}$, Schianchi ら ${ }^{24)}$ も五膜下出血後，攣縮動脈に

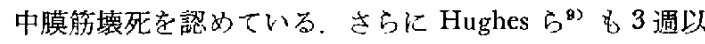
内に死亡した症例で攣縮動脈の中膜筋細胞に中等大の細 胞出現を認め “plump cell”と呼んでいる，そして貪食 細胞の可能性を示唆しているが，我々も第 2 群の変化を 示す標本に同様の紐胞の存在を認めた，以上の上5に諸 家が早期変化としている所見は寸べて著者の第 2 群の所 見に対応して扔り，血管の収縮状態走示すと思われるも っと早期の変化, つまり著者らの第 1 群の変化につい下 はまったく注日していない，しかし治療を考える上で， この第 1 群の装化は重要である。なぜなら, 我々の結果 からもわかるように，孌縮の持続時間さ之短ければ，あ るいは適切に治療されるなら, 第 2 群, 第 3 群へと移行 することなく寛解しら硛化であると考えられるからで ある.

第 2 群一と進行してしまった部分性不可逆性で，さら に第 3 群入と進行してゅく。これは diffuse narrowing を示す時期でもっとも narrowing の強かった部分が irー regular narrowing $の$ 時期でも narrowing として残存す ること，まを第 2 群の内膜变化は强く，中膜には平滑筋 堎死と酸性ムコ多精類の蓄積があり，線維細胞や膠原線 維の增加在きたすに十分な所見を有していることなどか らも訨明できる。

内膜の変化に関し，第 1 群では軽度浮腫状，第 2 群で は明白な浮腫状肥大, 内皮細胞脱落, 壁在血拴の存在を みる. Tanabe ら ${ }^{27}$ の実験でも早期に内皮細胞の変化を 
認めている，第 3 群の変化は，内膜の線維性肥屌と中膜 萎縮である，中膜萎縮については平滑筋壤死の部分が翏 原線維に置換された結果で当然と思われるが，内膜の肥 厚については，諸説が存在している．Someda ら ${ }^{25)}$ は血

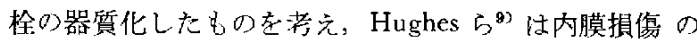
結果生じる内皮細胞下での楾維性增殖考考えている，我 ヶはこの内膜肥厚について，血栓の器質化と考えるには 肥厚の加られる時期が早すぎることこの内膜肥厚は segmental にみららそれ江 diffuse narrowing $の$ るとも 強度のところに一致してみられること，一度血栓が器質 化してし主えばその寛解はみられないのに゚，この内膜 肥厚には軽快がみられることなどから，等縮による内膜 損傷の結果生しる一時的な線維性増殖と考えている.

第 3 群でみられる内膜肥厚が時問の経過とともに軽快 し，内弾性板との間で線維融解が生じて肥厚の減少を示 すものが第 4 群の変化である。この所見は出血後49日目 以後に死亡した症例にみられており，女ちろんこの時期 に行われた血管撮影でも血管の narrowing はみられてい ない.

ここで一度増殖線維化した組織が可逆性を示すかとい う問題が生じる。一般に内膜の線維性増殖は動脈硬化䇥 を初めとして，種ヶの血管病変や血管外傷ですみられる 変化であり，一度線維化がおこれば可逆的変化法生じな い(1).これに反し，彎縮により生した内膜肥厚は出血発 作加ら日数を程るに伴い軽快している。乙礼は血管撮影 像の narrowing の宽解から女，晚期死亡例の病理像加ら も襄づけできる。Conway ら"注この線維性肥厚が永久 的変化でかるとしながらも，自らの実験結果から正常に 復寸る可能性を考虑して扣り，Tanabe ら ${ }^{27)}$ \&力月以 降のイヌの彎縮動脈にはこの内膜変化をまったく認めな いことから，完全に可逆的変化とみている。

内膜肥厚の可逆性ととるに，中膜平滑笳細胞の再生に 閣寸る問題がある. Tanabc $ら^{27}$ の実験で忙出血後 $3 \sim$ 7 日月に生じた筋細胞壊死が 1 年以上の期間を要して修 復されることを示している。また，我々の第 5 群の所見 がきわめて大きな意味をるってくる。これらの3 例で仕 160日 〜 3 作を経て死亡したものであり，内膜肥厚が軽 微で中膜平滑筋にも明らかな再生所胃索みしめており， 病変の治掩した所見とみなしらる。すなるち前項でとり あげた内膜の線維性肥厚，この中膜の萎縮は共に可逆性 変化であると考えざるをえない。

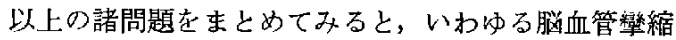
を示した腷動眽に扢る病理学的変化の時間的推移は Fig. 10 のよな解釈ができる。

次に第 2 群の所見を示す標本に存在するPAS，アル
シアンブルー染色陽性物質の問題か゚ある.この両染色で 陽性壱示寸の酸性ム二多糖類である。この物質は結合 組織中に広く存在して㧍り，血管壁の中にももち万ん存 在している。しかしその量はきわめて少ない，一方我々 の第 2 群の所見を有する部分の血管には異常に多くの蓄 積がみられてい石。Linzbach ${ }^{14}$ は組織に栄養障害があれ ば，崩壊した結合組織からムこ多精類の遊離が生じると 述べているが，この意見からみると，我々の第2群の血 管にこの異常増加がみられるのも理解できることであ 马.

実験的に血管線維症の研究齐行った Lorenzen ${ }^{152}$ は病 変の初期には代射回転が速いため七アルロン酸の增加 が主に認めら㞦ると述べて扣り，Klynstra ${ }^{13)}$ の研究も同 様の結果を示している，したがって，酸性ムコ多糖類の 中でもヒアルロン酸は急激な組織变性を示寸過程に重要 な役割を果たすものと考えられる，本研究で第 2 群の標 本にみられた酸性ムコ多糖類的ヒアルロン酸が主役をな して抢り，この時期の中膜に打ける変化が急性の代謝障 害によるものであることが裹づけられる。

\section{VI 結 論}

昭和47年 4 月より昭和53年10月まで奈良医大䍁神経外

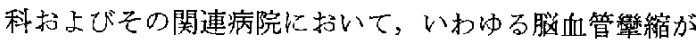
示され，かつ剖検しえた44症例を対象として，脳血管の 病理学的変化について調べた結果, 次の結諭主得た.

脳血管撮影所囬で汢，ク乇膜下出血発作後，3日目よ り15日頃までは diffuse narrowing 呈し，それ以後25日 頃までは irregular narrowing を示寸。また生存例ではそ の後に戀縮の宽解がみられる。これらの遒動脈の病理学 的所見汢 5 群に大别できる。

第 1 群 : 中膜肥大, 平滑筋の混濁腫脹, 内弾性板の著 明な屈曲蛇行

第 2 耗 : 中膜の平滑箭壊死, 内弾性板の断裂, 酸性么 二多糖類の異常普加，なおこの酸性ムコ多糖類はヒアル ロン酸である。

第 3 群 : 内膜の著明な線維性肥厚, 内弾性板の断裂・ 萎縮扁平化，中膜萎縮.

第 4 群：内膜肥厚の軽决, 中膜萎縮.

類 5 群 : 中膜平滑筋 0 再生.

以上の第 1 群から第 5 群までの病理学的変化は，以わ

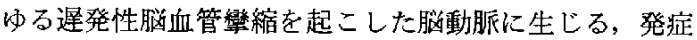
から治療までの病理学的変化を示するのである。

本論文の要旨は第37回譄神経外科学会総会（1978年熊 本）に妨てて発表した。 


\section{文献}

1) Adams, C. B. T., Fearnside, M. R. \& O'LAoIre, S. A.: An investigation with serial angiography into the evolution of cerebral arterial spasm following ancurysm surgery. $J$ Neurosurg 49: 805-815, 1978

2）相羽 正：脳動脈瘤の手術適忘と手術手技. 神経外科 $16: 467-478,1976$

3) Alksve, J. F. \& Greenhoot, J. H.: Fxperimental cathecholamine-induced chronic cerebral vasospasm. Myonecrosis in vessel wall. $J$ Neurosurg $41: 440-445,1974$

4) Conway, L. W. \& McDonald, L. W. Structural changes of the intradural arteries following subarachnoid hemorrhage. $J$ Neurosurg 37: 715-723, 1972

5) FcKer, A. \& Riemenschneider, P. A.: Arteriographic demonstration of spasm of the intracranial arteries. With special reference to saccular arterial ancurysms. $J$ Neurosurg 8: 660-667, 1951

6) Fein, J. M., Flor, W. J., Cohan, S. L. \& Parkhurst, J.: Sequential changes of vascular ultrastructure in expcrimental cerebral vasospasm. Myonecrosis of subarachnoid arteries. $\checkmark$ Neurosurg $41: 49-58,1974$

7) Fisher, C. M. \& Adams, R. D.: Observation on brain embolism with special reference to the mechanism of hemorrhagic infarction. $J$ Neuropathol Exp Neurol 10:92-94, 1951

8) Gurdjian, E. S. \&. Thomas, L. M.: Cerebral vasospasm. Surg Gynecol Obstet 129: 931-948, 1969

9) Hughes, J. T. \& Schiavchi, P. M.: Cerebral artery spasm. A histological study at necropsy of the blood vessels in cases of subarachnoid hemorrhage. $J$ Neurosurg 48: 515-525, 1978

10) Kamo, A.: Ultrastructural studies of experimental arteriosclerosis. Arterial lesions produced by repeated contraction. Acta Med Nagasaki 16 : $59-78,1972$

11）金弘，水上公宏，荒木五郎，吉田洋二：

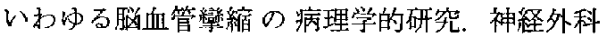
$16: 115-125,1976$

12) Kim, H., Mizukami, M., Kawase, T., Takemae, T. \& Araki, G.: Time course of vasospasm-Its clinical significance. Neurol Med Chir (Tokyo) 19: 95-102, 1979

13) Klynstra, F. B., Vander Laan, J. \& Linders, H. J.: Methods for the separation of acid mucopolysaccharides of the human aorta. $J$ Atheroscler
Res 7:257-264, 1967

14) Linzвach, A. J.: Vergleich der dystrophischen Vorgänge an Knorpel und Arterien als Grundlage zum Verständnis der Arteriosklerose. Virchozes Arch [Pathol Anat] 311:432-508, 1944

15) Lorenzen, I.: Biology in fibroblast. Academic Press, New York, 1975, 601 p

16) 宮嵫 誠, 野中利房, 渡辺 博, 千々崎裕夫, 石井昌三：脳血管綮縮の成因と治療に関する実 験的臨俰的研究。神経外科18:29-37, 1978

17）長久雅博：胋血管等縮実駼的研究一特に向色 素成分 $の$ 攣縮作用について一。大限市医学会雑 誌24:211-221，1970

18）新妻 博, 郭 隆嗓, 大井隆嗣, 片倉隆一, 瑇井和夫，鈴木二郎：脑動脈瘤破裂に伴なら脳

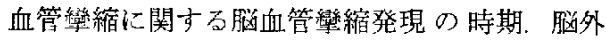
$6: 749-755,1978$

19）大根田玄寿：血管の病変，p44-97,宫地徹(編) ：臨床組織病理学。杏林晴院，東京，1975

20)太太田富雄, 川村純一郎, 苧坂邦彦, 梶川博, 半田 肇：“いわゆる”譄血管㘘縮の形態学的 分類一その子後との相関関係について一. 媨神 経24：427-435, 1972

21）齐藤 勇，位野圭司：脳神経外科法打万 Microsurgery. 脑動脈瘤手術に対与る応用. 外科 治療27:275-281, 1972

22) 柳 三郎，尾藤昭二：〈む膜下出血剖検症例 の政床病理学的研究. 媨神経23:143-151，1971

23) SAsAI, Y.: Identification of individual acid mucopolysaccharides in tissue sections. Tohoku $J$ Exp Med 105: 101-110, 1971

24) Schianchi, P. M. \& Houghes, J. T.: Cercbral artery spasm: Histological changes in necropsies of cases of subarachnoid hemorrhagc. Adv Neurol 20:521-534, 1978

25) Someda, K., Morita, K., Kawamtra, Y. \& Matumura, H.: Intimal changes following subarachnoid hemorrhage resulting in prolonged arterial luminal narrowing. Neurol Med Chir (Tokyo) 19:83-93, 1979

26) 園部 真, 鈴木二郎：タモ膜下出血後 $の$ 敛盀 管揧縮原因物質とその運命。神経外科 $18: 29$ 37,1978

27) Tanade, Y., Sakata, K., Yamadi, H., Ito, T. \& TakadA, M.: Cerebral vasospasm and ultrastructural changes in cerebral arterial wall. An experimental study $J$ Neurosurg 49: 229-238, 1978

28) Tani, E., Yamagata, S. \& Ito, Y.: Intercellular granules and vesicles in prolonged cerebral vasospasm. $J$ Neurosurg 48: 179-189, 1978 